\title{
Hepatitis B \& C Viral Markers Status in Icteric Children at a Tertiary Care Hospital
}

\author{
Matin $\mathrm{A}^{1}$, Islam $\mathrm{MR}^{2}$, Mirdha $\mathrm{AA}^{3}$, Mowla $\mathrm{MG}^{4}$, Khan $\mathrm{R}^{5}$, Islam $\mathrm{MR}^{6}$
}

\begin{abstract}
Background: Hepatitis B (HBV) and Hepatitis C virus (HCV) can cause important morbidity and mortality and are major causes of acute and chronic liver disease worldwide. Objectives: This study was an attempt to evaluate the seroprevalence rate of hepatitis B and C in jaundiced children who were admitted at Bangabandhu Sheikh Mujib Medical University. This would be helpful to take measure for the prevention of hepatitis $\mathrm{B}$ and hepatitis $\mathrm{C}$ infection in paediatric age group. Methodology: A total of 50 admitted jaundiced children of either sex selected randomly were studied during July 2004 to June 2005 in the Department of Paediatrics of Bangabandhu Sheikh Mujib Medical University. Venous blood was tested for HBsAg and anti-HBcAb (IgM) and anti-HCV viral markers by ELISA. Results: The HBsAg test was positive among $24.0 \%$, Anti-HBcAb (IgM) test positive in $14.0 \%$. HBsAg was positive in $66.66 \%$ of male children and $33.33 \%$ of female children. Sero positivity was more in the 10 years age group. Conclusion: This study shows high rate of HBsAg and AntiHBcAb IgM seropositivity among icteric sick children so, further studies with appropriate design \& sample size to be conducted.
\end{abstract}

Key words: $\mathrm{HBsAg}$, anti-HBcAb (IgM), anti-HCV, icteric children.

\section{Introduction}

Viral hepatitis is a major public health problem in developing as well as developed countries ${ }^{1}$. Hepatitis B virus (HBV) and $\mathrm{C}$ virus (HCV) are important cause of morbidity and mortality and are major causes of acute and chronic liver diseases worldwide ${ }^{2}$. These often lead to cirrhosis or primary hepatocellular carcinoma.

The prevalence of HBV infection varies from country to country and within countries, having a close association with behavioural, environmental and host factors ${ }^{2}$. It has been estimated that there are approximately 350 million HBV carriers in the world, of whom $80 \%$ are Asians ${ }^{3}$. In Europe and North America the incidence of known carriers is about 1 in 1000 people $^{4}$. Five percent of world population and it is estimated that 10 to 30 million people become infected with the virus each year worldwide; many of them are children and teenagers ${ }^{4}$. Many cases of acute hepatitis B occur sporadically with no known source and studies have shown that prior unrecognized infection is common ${ }^{4}$. Over $90 \%$ of infants, $50 \%$ of children and $5 \%$ of adults with acute hepatitis B will develop chronic or long- term infection ${ }^{3}$. The current prevalence of chronic hepatitis $\mathrm{B}$ based on seropositivity for HBsAg in Bangladesh ranges from $4.4 \%$ to $7.5 \%{ }^{5}$. However, among high-risk populations, the seroprevalence of HBsAg is as high as $29 \%{ }^{5}$. Other study shows about $7 \%$ to $10 \%$ population have hepatitis $\mathrm{B}$ infection and $3 \%$ to $5 \%$ pregnant mothers are carrying the hepatitis B virus in Bangladesh ${ }^{6}$. Carrier rate is very high, ranging from $9 \%-12 \%$ in Bangladesh, Korea, Myanmar, Thailand ${ }^{7}$. Up to $70 \%$ of cases of hepatocellular carcinoma are attributed to HBV infection ${ }^{8}$.

Hepatitis $\mathrm{C}$ is a particularly insidious disease. The annual incidence of $\mathrm{HCV}$ infection among general population in Bhutan, Indonesia, Myanmar, Sri-Lanka and Thailand are $1.3 \%, 2.5 \%, 3.9 \%, 1.4 \%$ and $0.74 \%$ respectively $^{7}$. It is estimated that approximately $3 \%$ of the world's population is infected with HCV. Prevalence ranging from less than $1.5 \%$ in Europe, USA, Canada, over $2.5 \%$ Africa and south-East Asia; $2.5 \%$ to $5 \%$ in the Western Pacific to up to $12 \%$ in the Middle-East ${ }^{9}$. An acute HCV infection is mostly asymptomatic; however, evolves towards chronicity in approximately $85 \%$ of cases. Long-term morbidity is

1. Dr. Abdul Matin, Assistant Professor, Department of Paediatrics, Shaheed Suhrawardy Medical College and Hospital, Dhaka

2. Dr. Md. Rafiqul Islam, Associate Professor, Department of Paediatrics, Shaheed Suhrawardy Medical College and Hospital, Dhaka

3. Dr. Md. Al-Amin Mridha, Assistant Professor, Department of Paediatrics, Shaheed Suhrawardy Medical College and Hospital, Dhaka

4. Dr. Md. Golam Mowla, Junior Consultant, Department of Paediatrics, Shaheed Suhrawardy Medical College and Hospital, Dhaka

5. Dr. Rita Khan, Medical Officer, National Institute of Chest Disease Research \& Hospital, Dhaka

6. Dr. Md. Reazul Islam, Internee Doctor, Dhaka National Medical College \& Hospital, Dhaka.

\section{Correspondence}

Dr. Abdul Matin, Assistant Professor, Department of Paediatrics, Flat\# A, Domino Nouva, Shajahan Road. Dhaka-1212; E-mail : amp.jul08@gmail.com Mobile : 01819261278 
characterized by cirrhosis, primary liver cancer and several extrahepatic manifestations, including cryoglobulin associated symptoms and a sub-type of non-Hodgkin B-cell lymphoma ${ }^{9}$. It is estimated that 2.6 to 3.9 million people which is around $2 \%$ to $3 \%$ of population of Bangladesh have Hepatitis $\mathrm{C}$ infection ${ }^{6}$. In most of the patients there may be no symptoms ${ }^{6}$. HBV and HCV are transmissible through blood transfusion, sexual contacts, very close contacts, over-crowding, and using common syringes and even without any known parenteral risk factors and the infection might end up with fatal conditions like liver cirrhosis and $\mathrm{HCC}^{6,7,8}$.

This study was an attempt to evaluate the seropositivity of $\mathrm{HBV}$ and HCV markers among icteric children admitted at Bangabandhu Sheikh Mujib Medical University, Dhaka.

\section{Methodology}

This cross-sectional study was conducted in the Department of Paediatrics and Department of Microbiology of Bangabandhu Sheikh Mujib Medical University, Dhaka, from July 2004 to June 2005. A total number of 50 children admitted with jaundice of one (1) to fifteen (15) years age of either sex were selected randomly by selecting every fifth children. The parents were explained the purpose of the study. Both the written \& verbal consent was taken from the parents without any coercion. When parents did not give consent for any particular case next case was selected. The exclusion criteria were very sick children, vaccinated against hepatitis B, children suffering from malignancy, parents didn't give consent for the study. History and clinical findings were recorded in pre-tested semi structured questionnaire. Three $\mathrm{ml}$ of venous blood was taken aseptically in plain dry sterilized test tube and serum was separated by centrifugation at a rate of $4000 \mathrm{rpm}$ for five minutes. The supernatant clear serum was collected in a dry screw-cap vial, labelled for individual subject and was stored at $-20^{\circ} \mathrm{C}$ till it could be tested. All samples were tested for $\mathrm{HBs} \mathrm{Ag}$, anti-HBcAb-IgM and anti $\mathrm{HCV}$ by ELISA technique using kits from DiaSorin S.N.I, Italy. Positive results were interpreted according to the manufacturer's recommendations.

\section{Results}

Table 1 shows the 24\% positive for $\mathrm{HBs} \mathrm{Ag}$ and $14 \%$ positive for Anti-HBc Ab (IgM). Table 2 shows the differences of sero-positivity in both the sexes.

Table 1: Seropositivity of the viral markers in jaundice children $(n=50)$

\begin{tabular}{|c|c|c|}
\hline \multirow[t]{2}{*}{ Variable } & \multicolumn{2}{|c|}{ Children with Jaundice $(n=50)$} \\
\hline & Number & Percentage \\
\hline HBsAg +ve & 12 & 24 \\
\hline Anti-HBc $(\operatorname{IgM})+$ ve & 7 & 14 \\
\hline Anti-HCV +ve & 0 & 0.0 \\
\hline
\end{tabular}

Positivity was higher in male children. HBsAg was positive in $66.7 \%$ of male and $33.3 \%$ of female children. The relationship of age with viral marker's seropositivityis shown in tablet 3. The viral markers HBsAg and Anti-HBc Antibody IgM were positive more in the age group 10 years and above with percentages of $58.3 \%$ and $57.1 \%$ respectively.

Table 2: Distribution of seropositivity of the viral markers in both the sexes

\begin{tabular}{lccc}
\hline Sex & HBsAg +ve & $\begin{array}{c}\text { Anti HBcAb } \\
\text { (IgM)+ve }\end{array}$ & $\begin{array}{c}\text { Anti } \\
\text { HCV +ve }\end{array}$ \\
\hline Male & $8(66.7 \%)$ & $5(71.4 \%)$ & 0 \\
Female & $4(33.3 \%)$ & $2(28.5 \%)$ & 0 \\
Total & $\mathbf{1 2}(\mathbf{1 0 0} \%)$ & $\mathbf{7 ( 1 0 0 \% )}$ & $\mathbf{0}$ \\
\hline
\end{tabular}

There was no history of blood and blood products transfusion among the positive cases for HBsAg, Anti-HBcAb IgM. Only in 2 cases there was history of blood and blood product transfusion but they were negative.

\section{Discussion}

Routine screening for hepatitis $\mathrm{B}$ requires assay of at least two serological markers. HBsAg is the first detectable serologic marker of infection to appear and is found in almost all infected person. Antibody to core antigen Anti-HBc Ab-IgM is valuable single serologic marker for $\mathrm{HBV}$ infection because it is present as early as HBsAg and continues to be present later in the course of the disease when HBsAg has disappeared.

Table 3: Shows the association of age with viral markers seropositivity in children

\begin{tabular}{lccc}
\hline $\begin{array}{l}\text { Age groups } \\
\text { (yrs) }\end{array}$ & HBsAg +ve & $\begin{array}{c}\text { Anti-HBcAb } \\
\text { (IgM)+ve }\end{array}$ & $\begin{array}{c}\text { Anti-HCV } \\
+\mathbf{+ v e}\end{array}$ \\
\hline$<5$ & $2(16.6)$ & $1(14.3 \%)$ & 0 \\
$5-9$ & $3(25.0)$ & $2(28.6 \%)$ & 0 \\
$>10$ & $7(58.3)$ & $4(57.1 \%)$ & 0 \\
Total (n=50) & $\mathbf{1 0}(\mathbf{1 0 0} \%)$ & $\mathbf{7 ( 1 0 0 \% )}$ & $\mathbf{0 0}$ \\
\hline
\end{tabular}

The fifty children who were admitted having apparent sign of yellow sclera, HBsAg were positive in $24 \%$ case and Anti-HBcAb IgM was positive in $14 \%$ cases respectively. Abe et $\mathrm{al}^{10}$ studied on children with liver disease in the age group 1 to 14 years, to find out prevalence of both HBV and HCV respectively. It was found that $65.6 \%$ was positive for HBV and $15.9 \%$ was positive for HCV. This high rate of positivity was probably for widespread endemicity in Russia of both the viruses. Study done by Mehnaz et $\mathrm{al}^{11}$ in Pakistan among children with liver disorders was tested for HBsAg and $37.5 \%$ was detected positive, which is similar with this study. A study by Islam et $\mathrm{al}^{12}$ in wide-spread age ranges, found that children suffering with viral hepatitis, $15.4 \%$ positive for HBsAg. Malathi et $\mathrm{al}^{13}$ in India was done a study for detection of a etiological factors of acute viral hepatitis 
of the children admitted in hospital and found hepatitis B $22 \%$ which is consistent with the present study. In the present study HBsAg was positive in $24 \%$ cases. It can be explained on the basis that this study was done in a tertiary hospital, where serious cases were referred from all over the country. In the present study the male percentage is higher. Male and female ratio was 2:1. In Bangladesh a study which covered a wide age range was found that prevalence of HBsAg was higher in male than female ${ }^{14}$. This correlates with the study done by Malik et $\mathrm{al}^{15}$ and another study was done Mehnaz et $\mathrm{al}^{11}$ in Pakistan, in which both the studies were hospital bases and selected age range was one to fifteen years and one month to fourteen years respectively, where they found acute viral hepatitis is higher in male than female. Gerety et $\mathrm{al}^{16}$ was done on children and showed that males are more likely to become HBsAg carrier than females and it appeared to reflect a greater risk of exposure to this sex group.

In this study, a higher percentage of HBV was detected in the age group 10 years and above. A study was done in India and was found that HBV positivity was high in age group 6-8 years $^{13}$. Toukan ${ }^{17}$ emphasized that exposure to $\mathrm{HBV}$, on the other hand, increases steadily with age, positivity was more prevalent in children. This strongly indicates child to child transmission of HBV infection during recreational activities in that society where social distinctions among play-mates do not exist. This transmission is horizontal. In this study blood and bloodproducts transfusion, did not play any role in causing seropositivity of hepatitis B viral markers. This is a positive sign; due to people awareness and quality of screening procedures with blood and blood products transfusion. There is also a dramatic improvement in using disposable items. Anti-HCV is detected during the course of acute hepatitis between 4 to 24 weeks and it disappears of over years. While in the chronic hepatitis $\mathrm{C}$, anti-HCV persists indefinitely. In this study, no case was detected positive for $\mathrm{HCV}$. HCV prevalence is $3 \%$ in most parts of the world ${ }^{18}$.

\section{Conclusion}

In the conclusion the study permits to conclude that high rate of $\mathrm{HBsAg}$ and Anti-HBc $\mathrm{Ab} \operatorname{IgM}$ seropositivity is present among icteric children. So, further studies with appropriate design \& sample size to be conducted.

\section{References}

1. Kliegman RM, Behrman RE, Jenson HB, Stanton BF. Nelson Textbook of Paediatrics. Saunders. Philadelphia.18th ed. vol 2, p.1682-87 2. Alter M J, Mast EE, Margolis H S. Strategies to prevent and control hepatitis B and C virus infections: a global perspective. Vaccine March. 1999;17:1730-3

3. Anna S F. 1998. Hepatitis B and C in Asians. University of Michigan. [Online]. Updated On: 21 January, 2005; Viewed on 12 May, 2005. Available at: http://www.femsdoes.org/conference/9th/9hepatitisbandcinasians.html 4. Millinship S. Hepatitis B, Health on the Net Foundation [Online]. Retrieved on 2005. Available at http://www.hon.ch /Library/Theme/ HepB/intro.html. 5. Kowdley KV. Epidemiology of Chronic Hepatitis B: Current PerspectivesSpecial Report from APASL [online]. Viewed on 12 August, 2005. Available at http://archieve.mail-list.com/hbv-research/ msg07707.html

6. Liver Foundation of Bangladesh. Hepatitis B and Some Information [Online]. Updated On: 21 January, 2005; Viewed on July 14, 2005. Available at: http://www.liverfoundationbangladesh.com/news.html

7. World health Organization. Health Situation in South-East Asia Region, 1994-1997 [Online]. Retrieved on 7/2/2005. Available at http://209.61.208.100/health_situt_94-97/ch5_2.4.htm

8. World health Organization. 1992. Global health situation and projections and estimates. World Health Organization, Geneva

9. Swiss Hepatitis C Cohort Study, Hepatitis C virus. [Online]. Viewed on 24 June, 2005. Available at: http://www.sevhep.unizh. cohort_specificinfo_main.html 10. Abe K, Hayakawa E, Sminov AV, Rossina AL, Ding X, Huy TT, Sata T, Uchaikin VF. Molecular epidemiology of hepatitis B, C, D and E viruses among children in Russia. J Clin Virol. 2004;30(1):57-61

11. Mehnaz A, Billo AG, Zuberi SJ. Liver Disorders in Children, Department of Pediatrics, Civil Hospital and PMRC Research Centre, Jinnah Postgraduate Medical Centre, Karachi. JPMA. 1990;40:62-64

12. Islam MN, Islam KMN, Islam N. Hepatitis B virus infection in Dhaka, Bangladesh. Bangladesh Medical Research Council. Bull, 1984 ;10 :1-6

13. Malathi S, Mohanavalli B, Menon T, Srilatha P, Sankaranarayanan V S, Raju B B, Ramathilalgam B, Thyagarajan S P. Clinical and Viral Marker Pattern of Acute Sporadic Hepatitis in Children in Madras, South India. J Trop Paediatrics. 1998;44:275-278

14. Zaki M H, Ahsan C R, Nasir T A, Saha S K. 1999. Seroepidemiology of Hepatitis B Virus Infection in Bangladesh. [Online]. Retrieved on July 2, 2005. Available at http://www.icddrb.org/pub/publication.jsp? classificationID=31\&pubID $=724$

15. Malik I A, Anwar C M, Luqman M, ahmed A, Sarfraz T, Qamar M A. The Pattern of Acute Viral Hepatitis in children- A Study based on seroepidemiology and Biochemical Profile. JPMA, 1987;37:314-317

16. Gerety RJ, Hoofnagle JH, Markenson JA, Barker LF. Exposure to hepatitis B virus and development of chronic HBsAg carrier state in children. The J Paediatrics 1974;84:664-5

17. Tauckan AU. Hepatitis B virus infection in Middle East: Aspects of epidemiology and liver diseases after infection. Gut 1996;38(2):2-4

18. Khan M. Hepatitis C will be a Major Health Issue in Bangladesh. Bangladesh Observer. Viewed on 3 December, 2004 http:/www.icddrb. org/pub/publication.jsp? classificationID $=31 \&$ pubID $=724$ 